\title{
Presence and Positivity of High Risk HPV with Increase in the Severity of Cytological Abnormalities Detected on Pap Smear: A Study of 40 Cases
}

\author{
Authors \\ Prof. Dr Meena Mittal, Prof. Dr C.V. Kulkarni, Dr Sachin Sharma, \\ Prof. Dr Ashok Panchonia, Dr Ankesh Kumar Jain, Dr Priya Jain \\ Corresponding Author \\ Dr Priya Jain
}

\section{Introduction}

Cervical cancer ranked second among most commonly diagnosed cancer and in less developed countries it is third leading cause of cancer related death among females ${ }^{[1,2,3]}$ It is estimated that each year, 527,000 new case occur and 275, 000 deaths. Globally, $15 \%$ of all cancer in females is cervical cancer. ${ }^{[2,4]}$. In India about $20 \%$ of all cancer related deaths is due to cervical cancer in women and is the number one cause of death in middle aged Indian women. ${ }^{[5]}$

Cancer cervix is a multifactorial disease. Human Papilloma virus (HPV) infection is the most important risk factor. ${ }^{[6]}$ It has been shown recently that cervical cancer is strongly associated with the presence of high risk or oncogenic Human Papilloma virus (HPV) types (up to $100 \%$ ). ${ }^{[7,8]}$ The HPV virus is belongs to the family Papovaviridae, genus papillomavirus. ${ }^{[9,10]}$ having double stranded, circular DNA. The HPV subtypes which specifically affect the anogenital tract are $16,18,31,33,35,39,45,51,52,56,58$, 66 and 69. ${ }^{[11] .}$ It is important to understand genomic organization of the virus to understand the oncogenic process induced by HPV that leads to development of cervical dysplasia. Significant regions include the early $(\mathrm{E})$, the late $(\mathrm{L}),{ }^{[12]}$ and the long control region (LCR). ${ }^{[13]}$ E6 binds with p53 tumor suppressor gene, causes its degeneration while E7 binds retinoblastoma gene products. $^{[14]}$ thus, inactivation of p53 and pRB leads to cell cycle progression ${ }^{[15]}$ and immortalization of normal cervical cells, so it is the expression of viral oncogenes E6 /E7 which is prerequisite for progression toward malignancy and maintenance of the cancerous phenotype ${ }^{[16,17]}$.As the severity of the lesion increases levels of E6/E7 also rises. ${ }^{[18,19]}$ E6 and E7 transcripts could be useful as markers of disease progression. ${ }^{[18]}$

Thus, the objective of the study is to evaluate the expression of E6/E7 mRNA of HPV types 16, 18, $31,33,35,39,45,51,52,56,58,59,68$ and 82 (which together accounts for $95 \%$ of cervical cancer $^{[4]}$ in cervical samples using flow cytometry and its correlation with epithelial cell abnormalities detected by pap smear.

\section{Materials and Methods}

This study was conducted in Department of Pathology, Mahatma Gandhi Medical College and Maharaja Yeshwant Rao Hospital, Indore, 
Madhya Pradesh, India. It is a prospective study .The study duration was one year from July 2017 to June 2018 Sample size for the study was of 40 cases.

\section{Material Required}

1. Sure Path vials.

2. Cytobrush with detachable head

3. Vortex

4. normal glass slides

5. Centrifuge machine

6. Pap stain.

7. Micro centrifuge

8. Micropipettes

9. Water bath $\left(65 \pm 1{ }^{\circ} \mathrm{C}\right)$

10. Flow cytometer with a $488 \mathrm{~nm}$ laser

11. Data acquisition and analysis software

12. Buffer A(Fixation Buffer)

13. Buffer B(Hybridization Buffer)

14. HPV E6/E7 Probe Cocktail

15. HPV E6/E7 Positive Control Cells

16. HPV E6/E7 Negative Control Cells

17. $4^{\circ} \mathrm{C}$ refrigerator and $-20^{\circ} \mathrm{C}$ freezer

$18.1 .5 \mathrm{ml}$ polypropylene micro centrifuge tubes

19. $15 \mathrm{ml}$ polypropylene conical tubes

20. Disposable DNase-free pipet tips

21 . Formaldehyde (37\% by weight, methanol stabilized)

\section{Method}

After obtaining informed consent 40 women attending Gynaecology OPD were randomly selected on the basis of inclusion criteria. A detailed history was taken.
All 40 selected women were examined per vaginally and by speculum after acquiring a detailed history and verbal consent from them. The woman was placed in dorsal lithotomy position. After proper positioning of the woman, cervix was viewed by introducing Sims' vaginal speculum and anterior vaginal retractor and external os was identified. Pap smears were made by introducing cervical brush/ cytobrush with a detachable head were inserted into the external os and rotating it through 360 degrees 8-10 times in clockwise direction near the squamo- columnar junction. The cellular material thus obtained was quickly, but gently smeared on a clean glass slide. The glass slide was then immediately put into the Coplin jar containing 95\% ethanol which acted as a fixative. The prepared smears were then stained according to Papanicolaou's technique.

The white head of the cervical brush was detached and put into the Sure Path preservative vial. Vial was then shaken well and stored at room temperature till the samples were processed for the run in flow cytometer. (Figure 1)

The cytological interpretation of the smears was made according to the new Bethesda system. Data collected for age, socioeconomic status, parity, clinical features and examination, results on conventional pap smear and flow cytometric analysis of HPV mRNA E6/E7 was organized, interpreted, compared and analysis on appropriate statistical software.

\section{Results \& Observation}

1. Analysis of pap smear

\begin{tabular}{|c|c|c|}
\hline Pap smear & No of. cases & $\%$ \\
\hline Total smear & 40 & 100 \\
\hline Inflammatory smear & 25 & 62.5 \\
\hline Epithelial cell abnormality & 15 & 37.5 \\
\hline $\begin{array}{l}\text { Atypical epithelial cells Of -Atypical squamous cells undetermined significance } \\
\text { [ASCUS] }\end{array}$ & 7 & 17.5 \\
\hline Atypical squamous cells Cannot exclude HSIL (ASC-H) & 2 & 5 \\
\hline Low grade squamous intraepithelial lesion (HPV/mild dysplasia /CIN I [LSIL] & 4 & 10 \\
\hline Malignancy & 2 & 5 \\
\hline
\end{tabular}




\section{JMSCR Vol||07||Issue||06||Page 689-698||June}

Table No. 1 shows that in the present study, 40 pap smears were analyzed showing the distribution pattern of various condition. Out of which acute inflammatory smear is $25(62.5 \%)$ and epithelial cell abnormality comprises 15 cases $(37.5 \%)$.

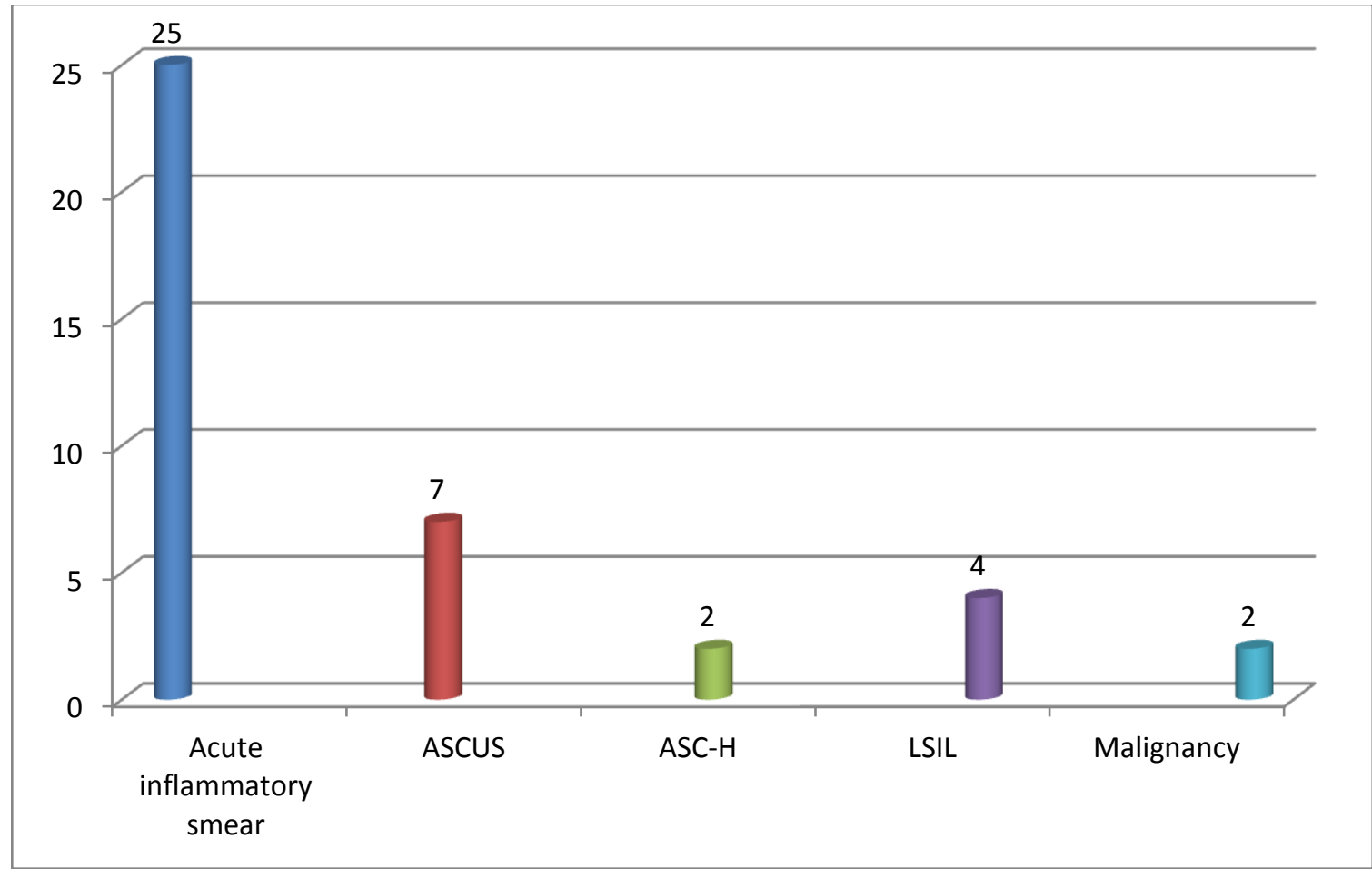

Graph 1- Analysis of pap smear

Table 2 Distribution of Negative for intraepithelial lesion or malignancy and Epithelial cell abnormality

\begin{tabular}{|l|c|c|}
\hline Cytological findings & No. of cases & Percentage\% \\
\hline Negative for intraepithelial lesion or malignancy & 25 & 62.5 \\
\hline Epithelial cell abnormality & 15 & 37.5 \\
\hline Total & 40 & 100.00 \\
\hline
\end{tabular}

Table 2 shows in the present study epithelial cell abnormality is $37.5 \%$.

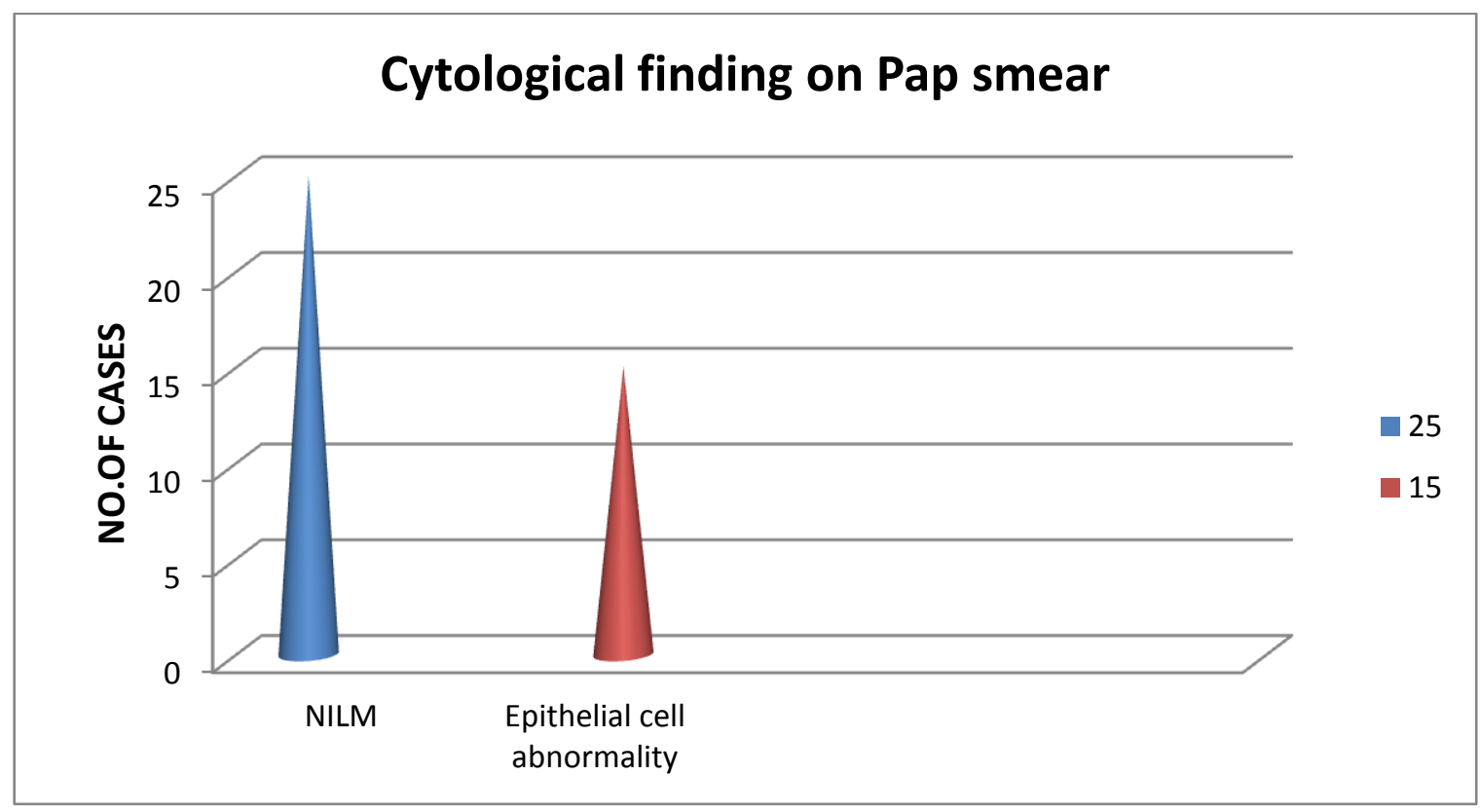

Graph 2 Distribution of NILM and Epithelial cell abnormality. 
3. Distribution of epithelial cell abnormality

\begin{tabular}{|l|c|c|}
\hline Epithelial cell abnormality & $\begin{array}{c}\text { No. of cases } \\
\mathrm{N}=15\end{array}$ & Percentage \% \\
\hline ASC-US & 07 & 46.66 \\
\hline ASC-H & 02 & 13.33 \\
\hline LSIL & 04 & 26.66 \\
\hline SCC & 02 & 13.33 \\
\hline
\end{tabular}

Table No 3 shows out of 15 cases of epithelial cell abnormality, 7 cases show Atypical squamous cells of uncertain significance, 2 cases show Atypical squamous cells of uncertain significance cannot exclude HSIL, 4 cases shows low grade squamous intraepithelial lesions. A total of 2 cases show invasive carcinoma cervix.

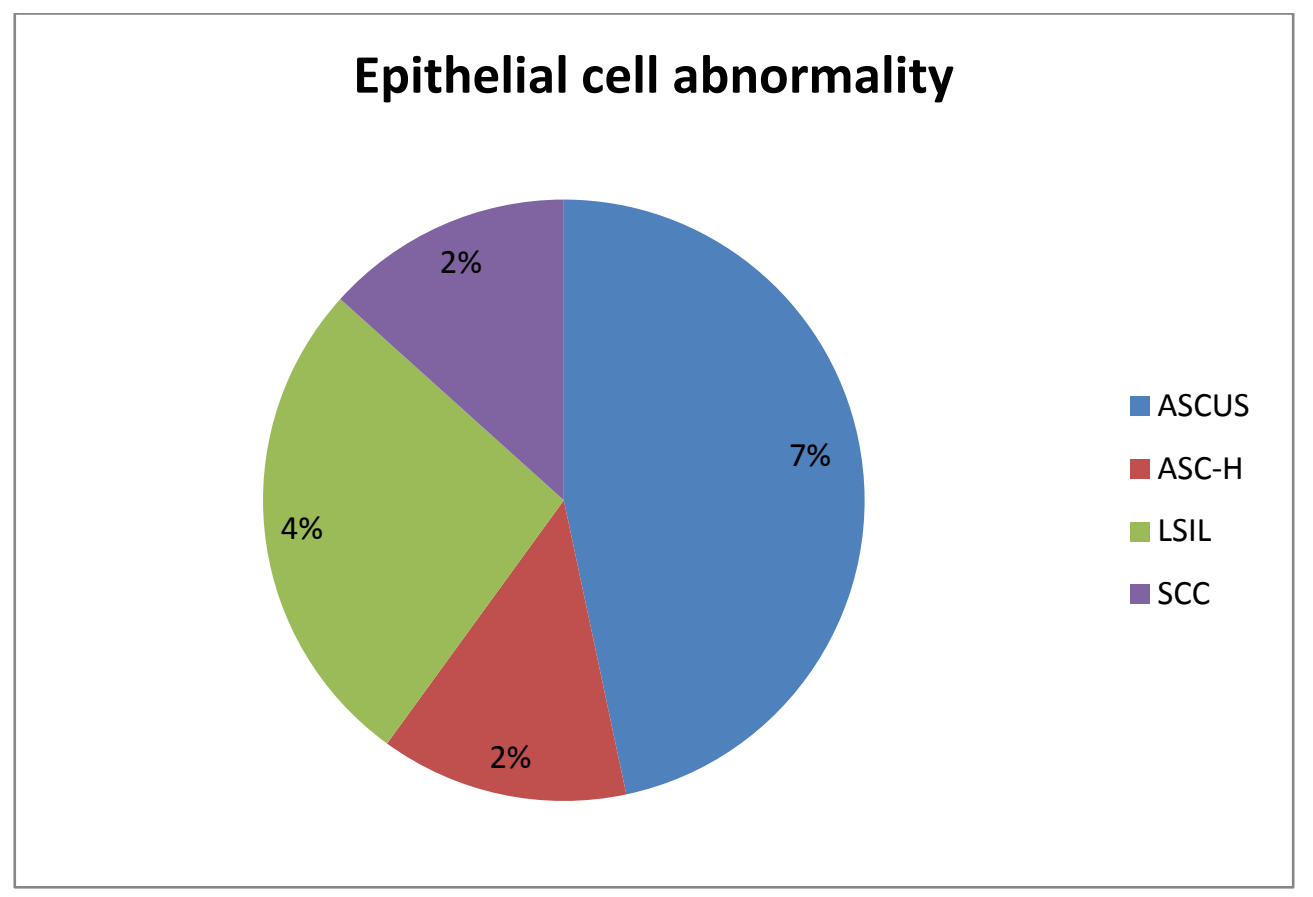

Graph 3 Distribution of epithelial cells abnormalities

4. Percentage positivity of HPV mRNA E6/E7 compared with severity of cytological diagnosis

\begin{tabular}{|l|c|c|}
\hline Cytological diagnosis & $\begin{array}{c}\text { No. of cases by } \\
\text { pap smear }\end{array}$ & $\begin{array}{c}\text { No. of cases positive for } \\
\text { HPV mRNA E6/E7 (\%) }\end{array}$ \\
\hline $\begin{array}{l}\text { Negative for intraepithelial } \\
\text { lesion or malignancy }\end{array}$ & 25 & $08(32 \%)$ \\
\hline ASCUS & 07 & $05(71 \%)$ \\
\hline LSIL & 04 & $03(75 \%)$ \\
\hline ASC-H & 02 & $02(100 \%)$ \\
\hline SCC & 02 & $02(100 \%)$ \\
\hline
\end{tabular}

Table no. 4 shows positivity of HPV mRNA E6/E7 increases with the severity of cytological evaluation. The positive rate of HPV mRNA E6/E7 rise from $32 \%$ for those who were negative for intraepithelial lesion or malignancy, $71 \%$ for
ASCUS and $75 \%$ for LSIL to $100 \%$ for carcinoma cervix.

It is also noted that HPV mRNA E6/E7 test detect extra 8 cases $(32 \%)$ which were labeled as negative for intraepithelial lesion or malignancy. 


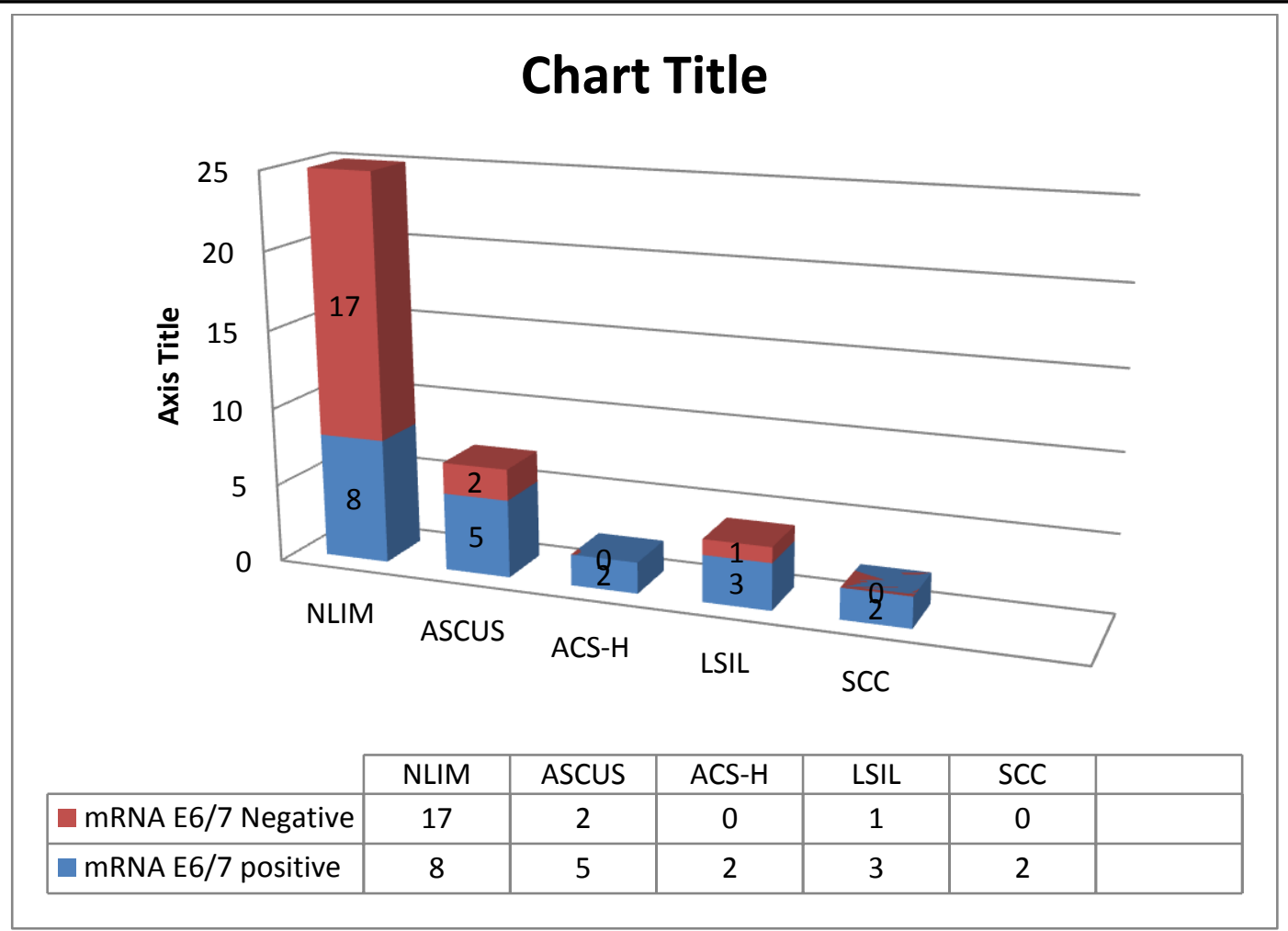

Graph 4 showing HPV mRNA E6/E7 positivity distribution in relation with cytological diagnosis on pap smear.

Figure 1 Flow Cytometry Set Up In Our Department

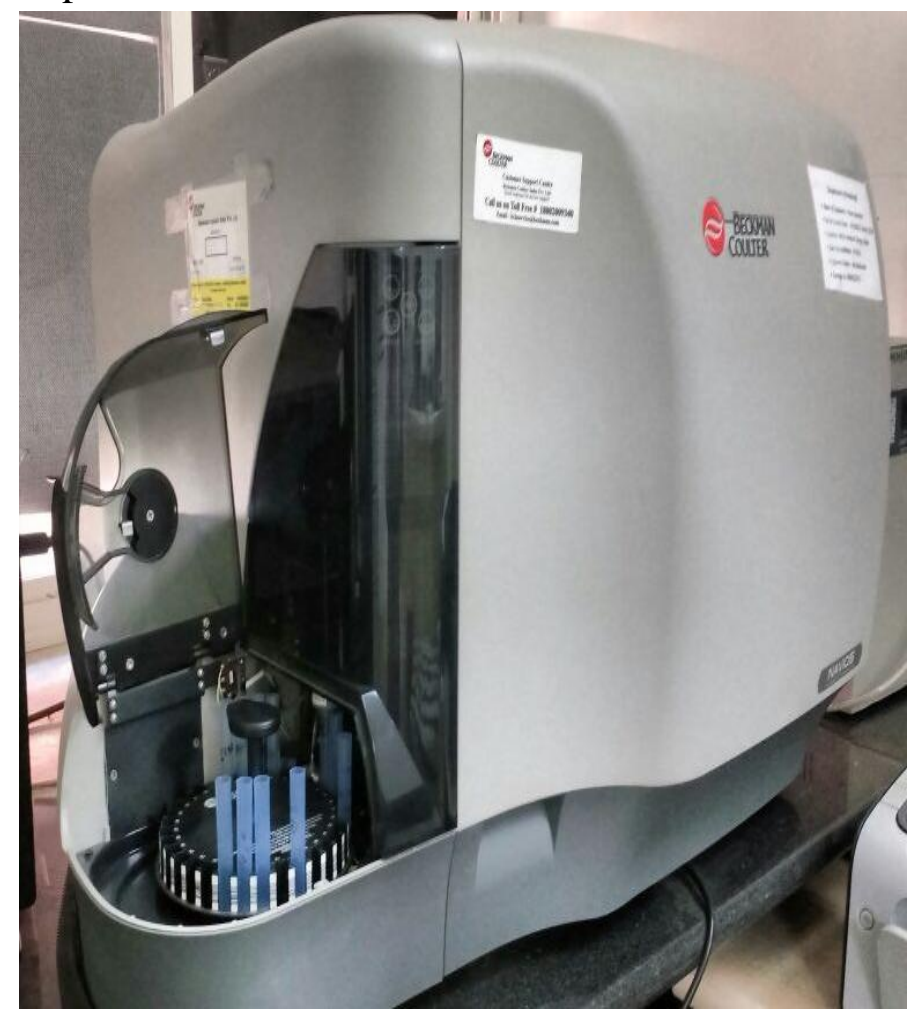

Figure 2 ASCUS on pap smear (low power)

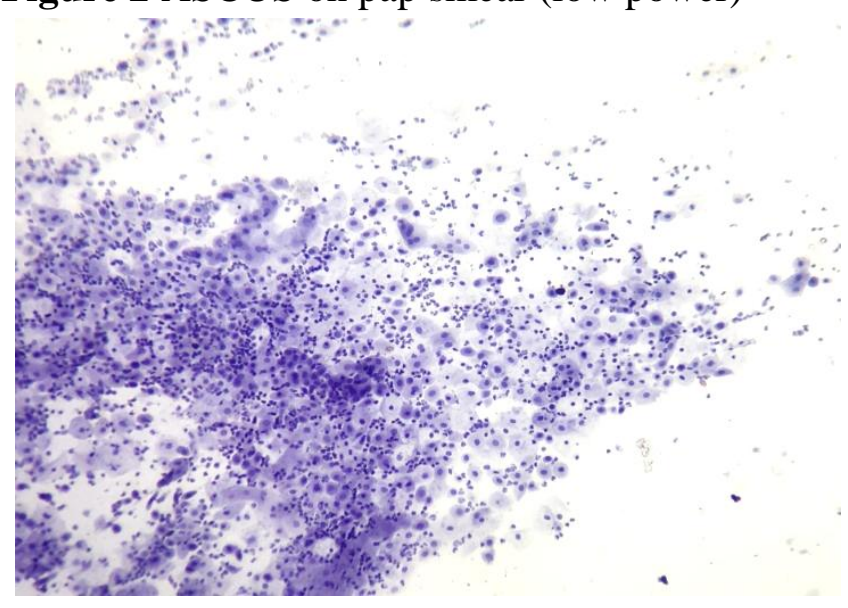

Figure 3 ASCUS on pap smear (high power)

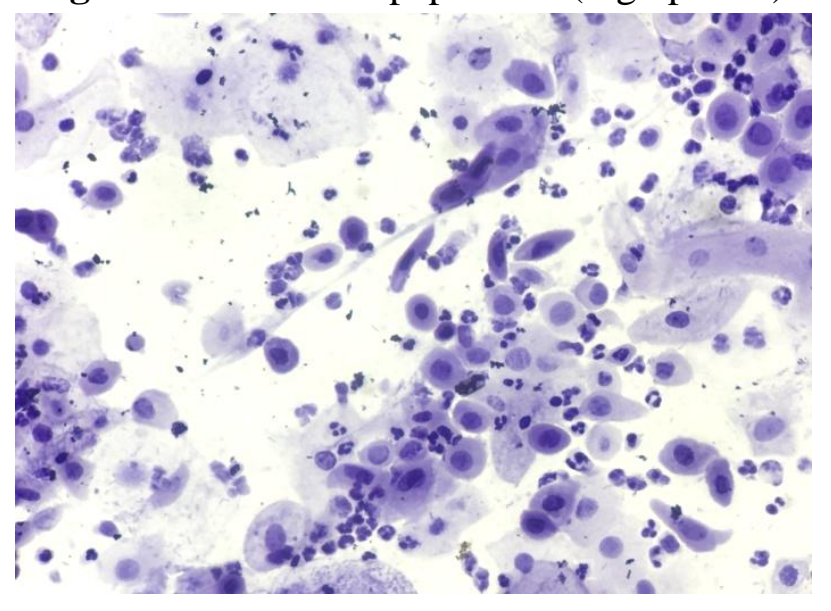


Figure 4 LSIL on pap smear (low power)

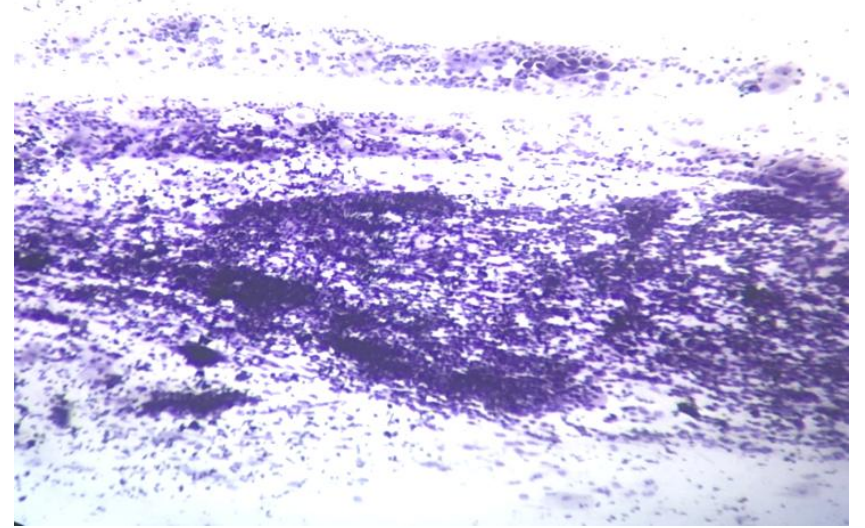

Figure 5. LSIL ON pap smear (high power)

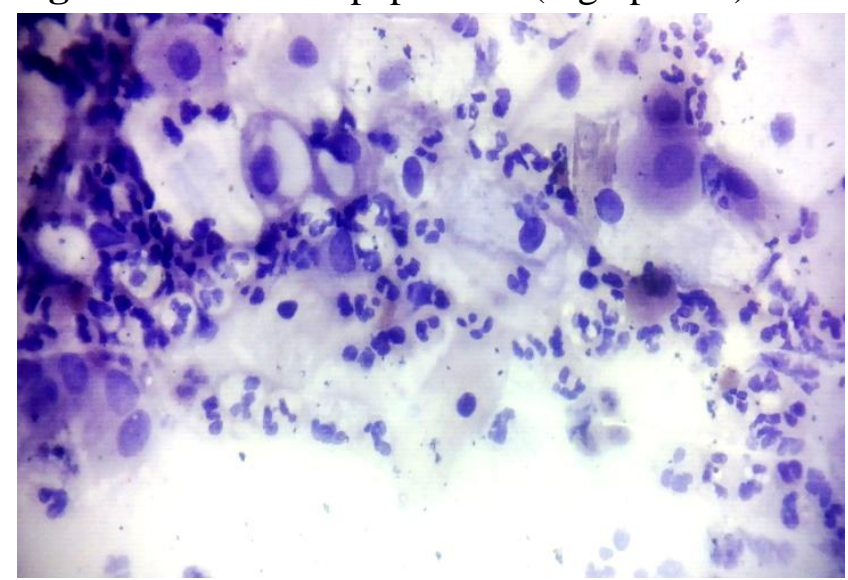

Figure 6 ASC-H on pap smear (low power)

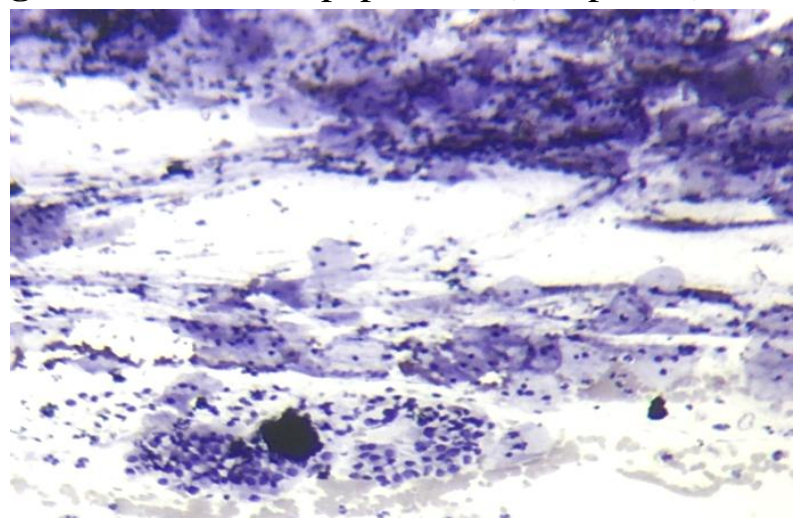

Figure 7 ASC-H on pap smear (high power)

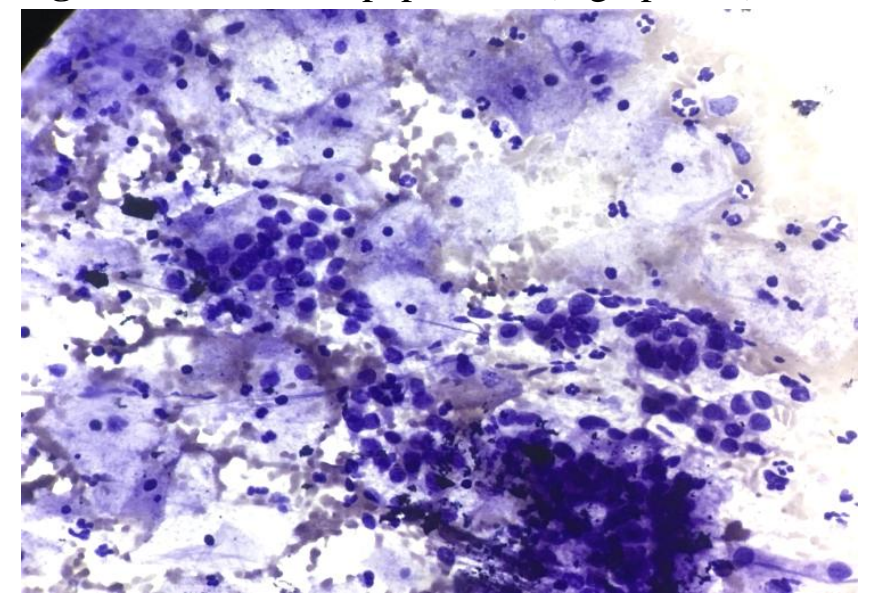

Figure 8 SCC on pap smear (low power)

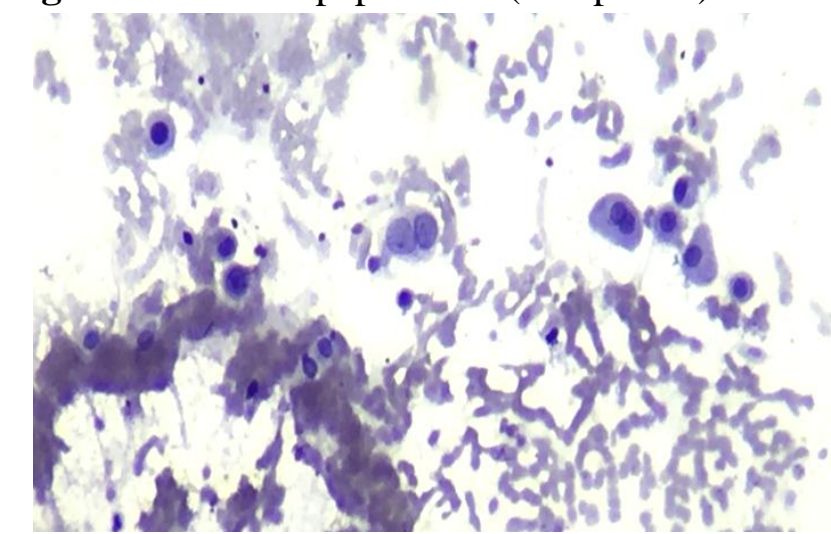

Figure 9 SCC on pap smear (high power)

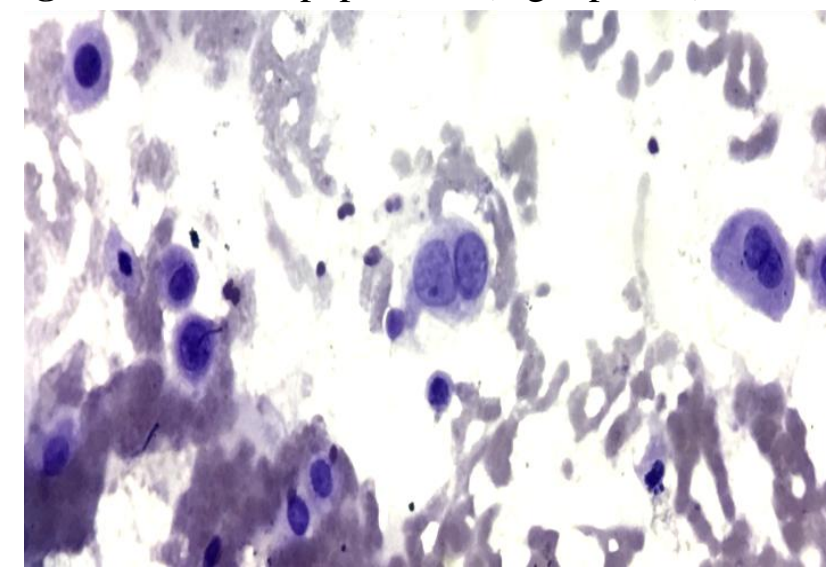

\section{Discussion}

The present study comprised of taking cervical samples of 40 symptomatic women attending the outpatient department of Obstretric \& Gynaecology and these cervical samples were processed for flow cytometric analysis of HPV E6/E7 mRNA detection and results were compared with pap smear to screen patients who are at risk for developing cervical cancer.

Our study revealed ASCUS (17.5\%) to be the most common epithelial cell abnormality. Similar results were obtained in other studies which also concluded that ASCUS to be the most common epithelial cell abnormality ${ }^{[20,21]}$. ASCUS progresses to LSIL, HSIL and SCC. AGUS progresses to adenocarcinoma. ${ }^{[22,23]}$

Fusté $\mathrm{P}^{[24]}$ (2008) and Insinga $\mathrm{RP}^{[25]}$ (2008) found that HPV is associated with more than $99 \%$ of all cervical cancer cases while in our study $100 \%$ cases with cervical carcinoma show hpv e6/e7 rmna positivity which is in favour with the result of our study. HPV causes almost $100 \%$ of cases of 
cervical cancer and limitation of study methodologies is most important reason behind an underestimation of HPV prevalence in cervical cancer. $^{\text {[26] }}$

In present study e6/e7 test is positive in $80 \%$ of women with ASCUS, ASC-H, LSIL or greater while it is $32 \%$ positive in women with negative cytology. Results are consistent with study conducted by Jefferson Elias Cordeiro Valença in 2016 in which $83.8 \%$ of women with $\mathrm{ASCH}$, HSIL, or greater is positive while, $57.9 \%$ of women presenting a negative cytology show E6/E7 test positive. cases which shows negative cytology and positive e6/7 test may be due to false positive cytology or it may be due to non evidence of morphological changes with viral integration into host genome ${ }^{[27,28]}$ According to $\mathrm{Li}$ and Kristensen, ${ }^{[29]}$ it could be the latent infection which presented with positive e6/7 test and negative cytology. Negative E6/E7 tests observed in women could be due to the presence of other types of HPV, not screened in this study. ${ }^{[29]}$

mRNA positivity increased with severity of cytological abnormality and ranged from 32\% (8/25) IN normal cytology to $71 \%(5 / 7)$ in ASCUS , $75 \%(3 / 4)$ in LSIL to $100 \%(2 / 2)$ in invasive cervical carcinoma. Similar was found in study conducted by Rijkaart ${ }^{[30]}$ et al in 2012 where it is $32 \%(64 / 202)$ in normal cytology to 47\%(41/88) in BMD and 68\% (58/85) in _BMD. This increase was statistically significant $\left(P_{-}\right.$ 0.01 ) as found in their study. Similarly ${ }^{[31]}$ Tong$\mathrm{Yu}$ Liua in 2013 The positive rate of mRNA rose from $29.0 \%$ (9/31) for those who were negative for intraepithelial lesion or malignancy, $21.5 \%$ (31/144) for atypical squamous cells of unknown significance, and $57.6 \%$ (19/33)for low-grade squamous intraepithelial lesion, to $59.8 \%$ (76/127) for more severe than high-grade squamous intraepithelial lesion..also stated by Cattani ${ }^{[32]}$ et al in 2009 E6 and E7 transcripts were detected in 20 of 80 patients with normal cytology findings (25\%) by the mRNA test. The proportion of patients with detectable transcripts increased progressively with the grade of the lesions observed, rising from $25 \%$ for patients with ASCUS (5/20 patients) to $50 \%$ for those with LSILs (23/46 patients) and $96 \%$ for those with HSILs or ASC-H (24/25 patients). All cases Pap smear positive for SCC were positive for HPV RNA.

VARNAI $^{[33]}$ et al in 2007 found that Expression of HPV E6/E7 mRNA was detected in 58\% while in OUR STUDY we found it to be 50\% (20/40). While Tong-Yu Liua ${ }^{[31]}$ in 2013 found that A total of $135(40.3 \%)$ patients were positive for HPV E6/E7mRNA.

In present study $80 \%(12 / 15)$ of patients with abnormal cytology show hpv e6/e7 mrna positivity while study conducted by Ozer Birge ${ }^{[34]}$ in 2018 found that $55.3 \%$ of patients with abnormal cytology show HPV E6/E7mRNA positivity. Pap smear has been used for the detection of preinvasive lesions. However, false negative values of $20-50 \%$ of a pap smear lead the researchers to find supplementary methods to increase the accuracy ${ }^{[35] .}$ In recent years, screening for HPV virus has become the interest of investigations. It is only the absence or presence of virus detected by HPV DNA; however, the potential of progression to invasive carcinoma and the probability of concomitant pre-invasive lesion cannot be predicted by the viral DNA test. Furthermore, lesions that will regress spontaneously are diagnosed and 'over-treatment' is made. By this way, the detection of E6/E7 mRNA proteins of human Papilloma virus seems to be more reasonable, as these are responsible for oncogenic transformation ${ }^{[36,37] \text {. }}$

Prevalence of HPV in our study is 50\% (20/40) which is in consistent with study done by rashmirani senapati in 2017 where they found prevalence to be $60.33 \%$. while the prevalence in case of invasive cervical cancer is $100 \%$ while rashmirani senapati ${ }^{[38]}$ found it to be $93.80 \%$.

\section{Conclusion}

From our study we came to conclusion that as severity of cytological abnormality increases percentage positivity of HPV mRNA E6/7 also 
increases. As per review of literature as HPV is most important risk factor for cervical carcinogenesis and its detection at molecular levels will help in early preventive measures rather than to wait for cytomorphological abnormality to appear.

\section{References}

1. Lindsey A. Torre; Freddie Bray; Rebecca L. Siegel; Jacques Ferlay; JoannieLortetTieulent; AhmedinJemal. Global Cancer Statistics, 2012. CA CANCER J CLIN 2015;65:87-108: 99-100.

2. Bojgua $\mathrm{S}$; Kldiashvili E. Liquid Based Cytology Cervical Cancer Screening Program - Georgian Experience. Arch Can Res. 2016, 4: 3.

3. Ekane, G.E.H et al. (2015) Pap smear Screening, the Way Forward for Prevention of Cervical Cancer? A Community Based Study in the Buea Health District, Cameroon. Open Journal of Obstetrics and Gynecology, 5, 226-233.

4. Gakidou E; Nordhagen S; Obermeyer Z (2008) Coverage of cervical cancer screening in 57 countries: Low average levels and large inequalities. Plos Med 5(6): e132. Doi:10.1371/journal. Pmed.0050132.

5. Basu Partha; Chowdhury Debjani. Cervical cancer screening \& HPV vaccination: a comprehensive approach to cervical cancer control. Indian J Med Res 130, September 2009, pp 241-246.

6. Schiffman M, Castle PE, Jeronim J, Rodrigue AC, Wacholde S. Human papillomavirus and cervical cancer. Lancet. 2007;370:890-907. [PubMed]

7. Van den Brule AJC, Walboomers JMM, du Maine M, Kenemans P, Meijer CJLM. Difference in prevalence of human papillomavirus genotypes in cytomorphologically normal cervical smears is associated with a history of cervical intraepithelial neoplasia. Int $\mathbf{J}$ Cancer 1991;48: 404-8.

8. Resnick RM, Comelissen MTE, Wright DK, Eichinger GH, Fox HS, ter Schegget $\mathrm{J}$, et al. Detection and typing of human papilloma virus in archival cervical cancer specimens by DNA amplification with consensus primers. J Natl Cancer Inst 1990;82:1477-84.

9. Kaufman RH, Adam E, Vonka V. Human papillomavirus infection and cervical carcinoma. Clin Obstet Gynecol 2000;43:363-80.

10. Harrison's principles of internal medicine. 14th Edition on CD-ROM.New York: McGraw-Hill, 1999

11. Khan S, Jaffer NN, Khan MN, Rai MA, Shafiq M, Ali A, Pervez S, Khan N,Aziz A, Ali SH: Human papillomavirus subtype 16 is common inPakistaniwomen with cervical carcinoma. Int J Infect Dis 2007, 11:313-317.

12. Gagnon D, Joubert S, Senechal H, FradetTurcotte A, Torre S, Archambault J: Proteasomal degradation of the papillomavirus E2 protein is inhibited by overexpression of bromodomain containing protein 4. J Virol 2009,83:4127-4139.

13. Muller Schiffmann A, Beckmann J, Steger G: The E6 protein of the cutaneous human papillomavirus type 8 can stimulate the viral earlyand late promoters by distinct mechanisms. J Virol 2006, 80:8718-8728

14. Porass C, Bennett C, Safaeian M, Coseo S, Rodriguez AC, Gonzaález P,Hutchinson M, Jimenez S, Sherman ME, Wacholder S, Solomon D, DoornLeen-Jan V, Bougelet C, Quint W, Schiffman M, Herrero R, Hildeshein A: Determinants of Seropositivity among HPV16/18DNA positive young women. BMC Infect Dis 2010, 10:238. 
15. Molecular biologists for Oncologists: Edited by: Yarnold JR, Stratton MR, Mcm Millan TJ. Chapman and Hall; , 2 1996:8388.

16. Fehrmann F, Laimins LA. Human papillomaviruses targeting differentiating epithelial cells for malignant transformation. Oncogene 2003;22:5201 7.

17. Boulet G, Horvath C, Vanden Broeck D, et al. Human papillomavirus:E6 and E7 oncogenes. Int $\mathrm{J}$ Biochem Cell Biol 2007;39:2006 - 11 .

18. Cattani P, Zannoni GF, Ricci C, et al. Clinical performance of human papillomavirus E6 and E7 mRNA testing for high-grade lesions of the cervix. J ClinMicrobiol 2009;47(12):3895-3901

19. Argyri E, Tsimplaki E, Daskalopoulou D, et al. E6/E7 mRNA expression of high-risk HPV types in 849 Greek women. Anticancer Res 2013;33(9):4007-4011

20. Patel M.M., Pandya A.N., Modi J. Cervical pap smear study and its utility in cancer screening, to specify the strategy for cervical cancer control. National Journal of Community Medicine; vol 2, issue 1, 2011.

21. Ghaith J.E., Rizwana B.S. - Rate of Opportunistic Pap smear Screening and Patterns of Epithelial Cell Abnormalities in Pap Smears in Ajman, United Arab Emirates. Sultan Qaboos Univ Med J; 12(4): 473-478, 2012.

22. Khan MS, Raja FY, Ishfaq G, Tahir F, Subhan F,Kazi BM et al. Pap smear Screening for Precancerous conditions of the cervical cancers. Pak J. Med. Res.

23. Edelman M, Fox A. Cervical Papanicolau smear abnormalities in inner Bronx adolescents: Prevalence, progression, and immune modifiers. Cancer (cancer cytopathology). 1999;87:184-9.

24. New therapeutic strategies for human papillomavirus related anogenital lesions in HIV patients: highly active antiretroviral therapy and HPV vaccines]. Fusté P, Santamaría X, Carreras R.Med Clin (Barc). 2008 Jun 7;131(1):30-4. Review. Spanish.PMID:18582422

25. A systematic review of the prevalence and attribution of human papillomavirus types among cervical, vaginal, and vulvar precancers and cancers in the United States. Insinga RP, Liaw KL, Johnson LG, Madeleine MM.Cancer Epidemiol Biomarkers Prev. 2008 Jul;17(7):1611-22. doi: $\quad 10.1158 / 1055-9965 . E P I-07-2922$. Review PMID:18628412 Free PMC Article

26. WHO/ICO HPV information centre. Human papillomavirus and related cancers. Summary Report Update.June 22,2010

27. Cernescu EC, Anton G, Ruţă S, Cernescu C. The effectiveness of cytological rescreening in the reduction of false negative/positive Pap reports. Roum Arch MicrobiolImmunol 2013; 72(2):93-104

28. Poomtavorn Y, Himakhun W, Suwannarurk K, Thaweekul Y, Maireang K. Cytohistologic discrepancy of highgrade squamous intraepithelial lesions in Papanicolaou smears. Asian Pac J Cancer Prev 2013;14(1):599-602

29. Lie AK, Kristensen G. Human papillomavirus E6/E7 mRNA testing as a predictive marker for cervical carcinoma. Expert Rev Mol-Diagn 2008;8(4):405-415

30. D. C. Rijkaart, D. A. M. Heideman, V. M. H. Coupe, A. A. T. P. Brink, R. H. M. Verheijen, H. Skomedal et al High-Risk Human Papillomavirus (hrHPV) E6/E7 mRNA Testing by PreTect HPV-Proofer for Detection of Cervical High-Grade Intraepithelial Neoplasia and Cancer among hrHPV DNA-Positive Women with Normal Cytology, Journal of Clinical Microbiology July 2012 ; Volume 50 (7) p. $2390-2396$ 
31. Nayar R; David C. Wilbur. The Bethesda System for Reporting Cervical Cytology, Third Edition, springer. ISBN 978-3-31911073-8 ISBN 978-3-319-11074-5, DOI 10.1007/978-3-319-11074-5

32. Ayre J. E; Dakin, E. Cervical Cytology Tests in Cancer Diagnosis: Glycerine Technique of Mailing, Canad. M. A. J. 54:489-491 (May) 1946

33. ALINDA D. VARNAI, MAGDOLNA BOLLMANN, AGNES BANKFALVI, NORBERT SPEICH, CHRISTOPH SCHMITT, HARALD GRIEFINGHOLT et al Predictive testing of early cervical pre-cancer by detecting human papillomavirus E6/E7 mRNA in cervical cytologies up to high-grade squamous intraepithelial lesions: Diagnostic and prognostic implications ONCOLOGY REPORTS 192008 p. 457-465.

34. Ozer Birge. Detection of HPV E6/E7 Mrna Using Nuclisens Easyq HPV ${ }^{\mathrm{TM}}$ in AbnormalCytology Specimens. J Gynecol Women's Health. 2018: 10(3): 555794. DOI: 10.19080/JGWH.2018.10.555794.

35. Boer DMA, Jordanova ES, Kenter GG, Peters AA, Corver WE, et al. High human papillomavirus oncogene mRNA expression and not viral DNA load is associated with poor prognosis in cervical cancer patients. Clin Cancer Res 2007,13(1): 132-138

36. Halfon P, Benmoura D, Agostini A, Khiri $\mathrm{H}$, Martineau A, et al. Relevance of HPV mRNA detection in a population of ASCUS plus women using the NucliSENS EasyQ HPV assay. J Clin Virol 2010, 47(2): 177- 181 .
37. Sorbye SW, Fismen S, Gutteberg TJ, Mortensen ES HPV mRNA test in women with minor cervical lesions: experience of the University Hospital of North Norway. J Virol Methods 2010,169(1): 219-222.

38. Rashmirani Senapati1, Bhagyalaxmi Nayak, Shantanu Kumar Kar and Bhagirathi Dwibedi HPV Genotypes distribution in Indian women with and without cervical carcinoma: Implication for HPV vaccination program in Odisha, Eastern India BMC Infectious Diseases (2017) 17:30DOI 10.1186/s12879-0162136-4. 